\title{
İnşaat Sektörünün Dayanıklılığını Konut Sunumunun Ötesinde Aramak
}

\author{
Esma AKSOY KHURAMi ${ }^{1 *}$
}

\begin{abstract}
Öz
Türkiye'de, özellikle 2000'li yıllardan itibaren inşaat sektörü ekonomiyi canlandırmak ve ev sahipliğini arttırmak amacıyla kamu politikalarıyla doğrudan desteklenmiştir. Bu amaca ulaşmak için kentler benzeri görülmemiş inşaat sahalarına dönüşmüş, imara yeni açılan alanlar aracılığıyla yeni konut üretimi gerçekleştirilirken, eskiyen kent dokuları yıkım ve yeniden yapım süreçlerine tanık olmuşlardır. Ekonomik büyüme inşaat sektörü eksenli olunca sonsuza kadar devam eder anlayışı güdülmüş, kamu ve özel sektör yatırımlarında inşaat yatıımları büyük paylar almaya başlamıştır. 2007 ve 2009 yılları arasında etkisini hissettiren Küresel Finansal Krizle beraber pek çok ülke inşaata dayalı ekonomik büyümeye mesafeli yaklaşmaya başlamış ve sektörün olası olumsuz etkilerini azaltmak için çeşitli tedbirler almıştır. Ancak Türkiye'deki genel eğilim bu yönde olmamakla beraber özellikle imara açılan yeni alanlar ve kentsel dönüşüm alanlarında inşaat faaliyetlerinin devam ettirilmesi sağlanmıştır. İnşaatın öncü olduğu bir büyüme modelinde sektörü kırılma noktasına getirebilecek tehlikeli sinyaller görmezden gelinmiştir. Bu çalışmada temelde, sektörün güçlü yönü kabul edilen sözde dayanıklıığını kırması olası değişkenleri saptamayı hedeflemektedir. Çalışmada 2005-2018 yılları arasında üretilen Türkiye İstatistik Kurumu (TÜIK) İnşaat Sektörü Eğilim İstatistikleri, İnşaat ve Konut İstatistikleri, Türkiye Odalar ve Borsalar Birliği (TOBB) Kurulan ve Kapatılan Şirket İstatistikleri, T.C. Merkez Bankası Konut ve İnşaat İstatistikleri kullanılacaktır.
\end{abstract}

ANAHTAR KELIMELER: İnşaat sektörü, Konut, Sektörel göstergeler, Dayanıklılık, Kırılganlık

\section{Searching the Sectoral Resilience of Construction Beyond Housing Supply}

\begin{abstract}
The construction sector in Turkey is directly supported through public policies in order to increase the share of owner-occupier households and to stimulate economic growth. In order to achieve these goals, new housing production has been realized with new development areas, while the old urban textures have witnessed demolition and rebuilding processes. Cities have transformed into unprecedented construction sites. The understanding of the unlimited economic growth with construction sector lasts forever that has shaped the construction investments in the public and private sector. With the impacts of the Global Financial Crisis between 2007 and 2009, many countries have begun to approach construction sector inquisitively and took various measures to reduce the potential adverse

\footnotetext{
${ }^{1}$ Orta Doğu Teknik Üniversitesi, Mimarlık Fakültesi, Şehir ve Bölge Planlama Bölümü, Ankara, Türkiye

*ilgili yazar / Corresponding author: aksoye@metu.edu.tr, esmaaksoy@mu.edu.tr

Gönderim Tarihi / Submission Date: 08.08.2019

Kabul Tarihi / Acception Date: 19.12.2019
} 
effects of the sector. As if there is no general tendency in other countries, in Turkey the continuation of construction activities has supported. In a growth model that the construction sector is a pioneer in, the ignorance of dangerous signals could bring the sector to the breaking point. This study aims to identify variables that are likely to break the so-called resilience, which is accepted as the most substantial aspect of the sector. In this study, Data produced by Turkish Statistical Institute (TURKSTAT) which are Construction Sector Tendency Statistics, Construction and Housing Statistics, also, by The Union of Chambers and Commodity Exchanges of Turkey (TOBB) Established and Closed Company Statistics, Central Bank Housing and Construction Statistics will be employed.

KEYWORDS: Construction sector, Housing, Sectoral indicators, Crisis, Vulnerability

\section{GiRiş}

Dayanıklı bir ekonomiyle devamlı kalkınma ve büyüme bütün ülkelerin erişmeyi amaçladığı iki temel hedeftir. Kalkınma ve büyümenin önünde engel oluşturabilecek olan her türlü kırılganlık ise saptanması ve üstesinden gelinmesi gereken engeller olarak görülmektedir. Ülkelerin kırılganlıklarını hangi araçlarla, öncü sektörlerle ve stratejilerle bertaraf ettiği farklılaşsa da buluştuğu bazı ortak paydalar bulunmaktadır. Özellikle 2008 Küresel Finansal Krizi ile beraber pek çok ülke krizden doğrudan etkilenmese dahi inşaat, konut ve ilişkili sektörlere tedbirle yaklaşmaya başlamış, sosyal, ekonomik ve demografik yapılarında bu sektörlere bağlı kırılganlıkların oluşmasını önlemeye çalışmıştır. Türkiye'de bu sektörlere yaklaşım pek çok açıdan diğer ülkelerden farklılaşmıştır. 2002 yılından itibaren odağı niceliksel inşaat istatistikleri olan hedefler konulmuş ve bu hedeflere ulaşmak için bütün kaynaklar seferber edilmiştir. Bu hedeflerin gerçekleştirilmesiyle ulaşılması amaçlanan politikaların başarı düzeyi ve uygulamaların ülke ekonomisine etkisi çoğu zaman tartışılmamıştır. Mevcut politikaların sürdürülebilirliğinin istenilen sonuca ulaştırma başarısıyla saptanması göz ardı edilmiştir. Sürdürülebilirliğin tespiti için değerlendirilmesi gereken değişkenler ve olumsuz sonuçlar için önlem alınmadığı durumunda karşı karşıya kalınacak olası sorunların ortaya konması bu çalışmanın en temel motivasyonunu oluşturmaktadır.

$\mathrm{Bu}$ çalışma ekonomisinde önceliği inşaat ve konut sektörlerine ve bu sektörlere ilişkin hedeflere ulaşmaya veren Türkiye örnekleminde OECD'nin belirlediği sektörel kırılganlıkları saptamaya yönelik erken uyarı göstergelerinden yararlanarak şekillenmektedir. Çalışmada ekonomik sektörler için dayanıklıık ve kırılganlık kavramlarının nasıl ele alındığına ilişkin yazın taramasının yanı sıra, Türkiye'de inşaat ve konut sektörlerinin son 10 yılına ilişkin değişimlere açımlayıcı analizlerle yer verilmiştir. Çalışmanın son kısmını oluşturan tartışma bölümünde ise kırılgan hale gelen konut sektörünün farklı paydaşlar için hangi sonuçları doğurabileceği ve olası senaryolara değinilmiştir.

\section{EKONOMIK SEKTÖRLER IÇiN DAYANIKLILIK VE KIRILGANLIK KAVRAMLARI}

İlk olarak biyolojik bilimlerin değişen sistemlerin eski haline ya da yeni denge durumuna dönmesini ifade etmek için kullandığı uyum kapasitesi ve dayanıklııı (resilience) kavramları son yıllarda birçok disiplin tarafından kullanılmaktadır. Bir değişime veya beklenmedik bir olaya karşı direnç oluşturabilmek, dayanıklı olmak, en az hasarı alarak atlatmak, çabuk iyileşme ve zorlukları yenme gücü olarak tanımlanan dayanıklıık kavramını ifade etmek için genişleyen kullanım alanlarıyla beraber yararlanılan yorumlar ve tanımlar da gelişmektedir. Disiplinler arası farklılaşmanın yanı sıra dayanıklıı̆ın ölçümü ve sistemin dayanıklı olması beklenen süreçlerde değişmektedir. Kırılganlık ise sistemin, yapının ya da sektörün dayanıklılığı önünde özellikle krizin atlatılması için engel oluşturabilecek hatta krizin kendisine sebep olabilecek her türden bileşeni ifade etmektedir (Downing et al., 2005; 
Ionescu et al. 2009). Bazı yazarlar dayanıklılığı kriz ya da beklenmedik bir olaydan önceki süreçle mücadele, bazıları kriz süresince dayanabilme gücü olarak tanımlarken bazı çalışmalar da dayanıklılıktan kriz sonrası süreçte yeni kapasitesini ve düzenini en kısa sürede oluşturabilme gücü olarak bahsetmektedir. Değişimden öncesine vurgu yapan Alberti ve diğerlerine (2003) göre kentsel dayanıklılık, kentlerin yeni yapı ve süreçleri organize etmeden değişime tahammül edebilme derecesini gösterir. Adger (2000) ise dayanıklı olmayı sistemin kendini değiş̧irmeden bazı değişken ve süreçleri dönüştürerek olası etkileri önleyici mekanizmalar oluşturabilme kapasitesi olarak tanımlar. Kriz sürecinde gösterilen baş etme becerisini dayanıklılık olarak tanımlayan yazarlardan Godschalk (2003) ise dayanıklı sistemlerden biri olan dirençli şehirleri ciddi şoklara kalıcı zarara uğramadan ve kaos yaşamadan atlatabilen kapasiteye sahip birimler olarak tanımlamıştır. Kriz sonrasına odaklanan Callister' a göre ise dayanıklılık bir malzemenin, yüzeyin, yapının ya da sistemin deformasyona sebep olan bir darbeden sonra orijinal şekline veya konumuna geri dönebilme özelliğidir (Callister, 2000).

Doğal sistemlerde meydana gelen kriz ve sonrasındaki değişimlerin yanı sıra tecrübe edilen ekonomik krizler de kentlerin ve ülkelerin ekonomik yapı ve sektörlerinin dayanıklılığının sorgulanmasına sebep olmuştur. Küreselleşme ve beraberinde gelen içsel ve dışsal ekonomik süreçlerle baş edebilen sistemler dayanıklı ve meydana gelen değişikliklere yüksek uyum kapasitesiyle bağlanabilen ekonomiler olarak adlandırılmıştır (Rose ve Spiegel, 2011; Lo Duca ve Peltonen, 2013). Özellikle 2008 Küresel Finansal Krizi'nde gözlenen konut ve inşaat sektörü eksenli büyüme ve finansal sistemler oluşturma anlayışı beraberinde likidite sıkıntısını doğurmuş ve bu kriz başta Amerika olmak üzere pek çok ülkenin konut ve inşaat sektörünü gözden geçirmesine neden olmuştur. Ülkeler ekonomilerini yaşanan krizlerden korumak ve olası krizlere karşı dayanıklı hale getirmek için kırılganlıklarını saptama yoluna gitmiştir (Christopherson ve diğerleri, 2010).

Ekonomik Kalkınma ve İşbirliği Örgütü (OECD) ekonomilerin düşebileceği çıkmazları (küçük ve büyük çaplı krizleri) sektörlere ilişkin erken uyarı göstergelerini gözlemleyerek ortaya koymaya çalışmıştır (Röhn ve diğerleri, 2015; Hermansen ve Röhn, 2015). Finansal sektör, finansal olmayan sektör, kamu sektörü ve varlıklar piyasasındaki dengesizlikler ile dışsal risk ve değişimleri yorumlayarak ülke ekonomilerinin karşı karşıya olduğu tehditleri uluslararası kıyaslamalarla ortaya koymuştur. Bu çalışmada OECD'nin araştırmalarından farklı olarak Türkiye'de özellikle son 15 yılda dengeli sektörel büyüme olmaması sebebiyle ulusal hedeflere konu olan inşaat ve konut sektörlerine ilişkin krize yol açabilecek erken uyarı göstergeleri yeniden yaratılarak değerlendirilmiştir.

Tablo 1'de üç farklı değişken grubu bulunmaktadır. Bu gruplardan ilkini doğrudan OECD'nin kullandığı değişkenler olan reel konut fiyatları, konut fiyatının hane halkının kullanılabilir gelirine oranı, konut fiyatı izafi kira oranı değişkenleri oluşturmaktadır. İkinci grup Türkiye'de ilgili verilere ulaşmak mümkün olmadığı için OECD tarafından kullanılan değişkenlerin muadili yaratılarak yorumlanan değişkenler kümesidir. Son grup ise çalışma için özgün değer taşıyan inşaat ve konut sektörlerindeki kırılganlıkları ulusal piyasada ortaya koyabileceği düşünülen konut üretim-satış düzeyleri, konut sahipliği değişkenleri ve yorumlarından oluşmaktadır. Çalışmaya konu olan verilerin bir kısmında coğrafi kod bulunması, bir kısmının ise ülke ya da bazı iller genelinde kalması Türkiye geneli değerlendirmeler yapmayı zorunlu kılmıştır. İlgili verilerin toplanmaya başlandığı yıllar arasında farklar olması da genel değerlendirme açısından birtakım eksikliklere sebep olmaktadır. Örneğin konut finansmanına ilişkin düzenlemeler 2007 yılında yapılmasına karşın, "Ipotekli konut satın alan hane halklarının oranı" tanımlı veri en erken tarih olarak 2013 yılını kapsamaktadır.

Bahsi geçen kısıtlar yapılan çalışmanın geçerliliği önünde ciddi bir engel oluşturmamaktadır. İnşaat sektörünün dayanıklılığını sadece konut sunumunun niceliksel büyüklüğüyle 
saptamanın sığ bir yaklaşım olduğu argümanının kabulüyle, dayanıklılık ve kırılganlığın tespitinde farklı değişkenlerin sorgulanması da çalışmanın özgün kısmını oluşturmaktadır.

Tablo 1. İnşaat ve konut sektörleri kırılganlık göstergeleri

\begin{tabular}{|c|c|c|c|}
\hline $\begin{array}{l}\text { Değişken } \\
\text { türü }\end{array}$ & Gösterge & Tanımı & Veri kaynağı \\
\hline \multirow{3}{*}{$\begin{array}{l}\text { Doğrudan } \\
\text { kullanılan } \\
\text { değişken }\end{array}$} & Reel konut fiyatları & $\begin{array}{l}\text { Yeni olan, yeni olmayan ve tüm } \\
\text { konutlar için konut fiyat endeksi }\end{array}$ & $\begin{array}{l}\text { T.C. Merkez Bankası, } \\
\text { Konut ve İnşaat } \\
\text { İstatistikleri (2013-2018) }\end{array}$ \\
\hline & $\begin{array}{l}\text { Konut fiyatının hane } \\
\text { halkının kullanılabilir } \\
\text { gelirine oranı }\end{array}$ & $\begin{array}{l}\text { Genel ve farklı kategorideki } \\
\text { hane halkları için konut fiyatının } \\
\text { hane halkının kullanılabilir } \\
\text { gelirine oranı }\end{array}$ & $\begin{array}{l}\text { TÜIK, Mikro Veri Seti, } \\
\text { Hane Halkı Bütçe Anketi } \\
(2005-2016)\end{array}$ \\
\hline & $\begin{array}{l}\text { Konut fiyatı izafi kira } \\
\text { oranı }\end{array}$ & $\begin{array}{l}\text { Hane halkının sahip olduğu } \\
\text { konutun fiyatının konutun izafi } \\
\text { kirasına (konutun kiraya } \\
\text { verilmesi durumunda ödenmesi } \\
\text { gereken kira) oranı }\end{array}$ & $\begin{array}{l}\text { TÜlK, Mikro Veri Seti, } \\
\text { Hane Halkı Bütçe Anketi } \\
\text { (2005-2016) }\end{array}$ \\
\hline \multirow{6}{*}{$\begin{array}{l}\text { Muadili } \\
\text { yaratılmış } \\
\text { değişken }\end{array}$} & \multicolumn{3}{|c|}{ OECD'nin kullandığı: İnşaat sektöründe çalışan iş gücünün toplam istihdamdaki payı } \\
\hline & $\begin{array}{l}\text { Yeni yaratılan: İnşaat } \\
\text { sektörü ile ilgili } \\
\text { şirketlerin niceliksel } \\
\text { değişimi }\end{array}$ & $\begin{array}{l}\text { Açılan ve kapanan inşaat ve } \\
\text { gayrimenkul şirketleri tüm açılan } \\
\text { ve kapanan şirketlerdeki payı }\end{array}$ & $\begin{array}{l}\text { TOBB, Kurulan/Kapanan } \\
\text { Şirket İstatistikleri (2010- } \\
\text { 2018) }\end{array}$ \\
\hline & $\begin{array}{l}\text { Yeni yaratılan: İnşaat } \\
\text { sektörü gelecek } \\
\text { beklentisi }\end{array}$ & $\begin{array}{l}\text { Sektörel güven endeksi, Çalışan } \\
\text { kişi sayısı ve satış fiyatları } \\
\text { beklentisi }\end{array}$ & $\begin{array}{l}\text { TÜİK, İş Yeri Eğilim } \\
\text { İstatistikleri, (2011-2019) }\end{array}$ \\
\hline & \multicolumn{3}{|c|}{ OECD'nin kullandığı: Konut borçlarının toplam borçlar içindeki payı } \\
\hline & $\begin{array}{l}\text { Yeni yaratılan: } \\
\text { İpotekli-yeni ve eski } \\
\text { konut satışlarının } \\
\text { toplam satışlardaki } \\
\text { payı }\end{array}$ & $\begin{array}{l}\text { İpotekli konut satın alan hane } \\
\text { halklarının oranı }\end{array}$ & $\begin{array}{l}\text { T.C. Merkez Bankası, } \\
\text { Konut ve İnşaat } \\
\text { İstatistikleri (2013-2018) }\end{array}$ \\
\hline & $\begin{array}{l}\text { Yeni yaratılan: Konut } \\
\text { borcu olan hane } \\
\text { halklarının oranı }\end{array}$ & $\begin{array}{l}\text { Herhangi bir kaynaktan borç alıp } \\
\text { konut ilişkin borç ödemesi } \\
\text { devam eden hane halklarının } \\
\text { toplam hane halkları içindeki } \\
\text { payı }\end{array}$ & $\begin{array}{l}\text { TÜIK, Mikro Veri Seti, } \\
\text { Hane Halkı Bütçe Anketi } \\
(2005-2016)\end{array}$ \\
\hline \multirow{2}{*}{$\begin{array}{l}\text { Özgün } \\
\text { değişken }\end{array}$} & $\begin{array}{l}\text { Konut üretim ve satış } \\
\text { düzeyleri }\end{array}$ & $\begin{array}{l}\text { Toplam satışlar içerisinde ilk el, } \\
\text { ikinci el ve ipotekli konutların } \\
\text { satış oranları }\end{array}$ & $\begin{array}{l}\text { T.C. Merkez Bankası, } \\
\text { Konut ve İnşaat } \\
\text { İstatistikleri (2013-2018) }\end{array}$ \\
\hline & Konut mülkiyet şekli & $\begin{array}{l}\text { Hane halklarının oturdukları } \\
\text { konutlardaki mülkiyet } \\
\text { biçimlerinin değişimi }\end{array}$ & $\begin{array}{l}\text { TÜİK, Mikro Veri Seti, } \\
\text { Hane Halkı Bütçe Anketi } \\
(2005-2016)\end{array}$ \\
\hline
\end{tabular}

\section{INŞAAT VE KONUT SEKTÖRLERININ KIRILGANLIKLARININ SAPTANMASI}

Kırılganlık sistemleri şoklara karşı savunmasız hale getiren ve onların işleyişini bozan önemli bir sorundur. Ülkelerin kalkınmışlık düzeylerine göre değişmekle beraber kırılganlığa neden olan etmenler ekonomiler için ilk etapta hızlı büyüme eğrilerine ulaşmayı sağlarken farklarına varılmadıkları, ilişkili oldukları sektörlerin sınırsız ve kontrolsüz desteklendikleri süreçlerde kritik eşiklerini aşarak ciddi ekonomik krizlere sebep olabilmektedir. 1980 sonrası süreçte etkisini sadece ekonomide değil sosyal, kültürel ve çevresel yapıdaki değişimlerde de gösteren yapılı çevre inşa faaliyetleri özellikle 2000'li yıllarda pek çok ülkede zirve seviyelerine erişmiştir. Sınırsız ve kontrolsüz bir biçimde büyümenin ön koşulu kabul edilen 
inşaat ve konut yatırımları kamu ve özel sektörün yoğun çabalarıyla desteklenmesine rağmen pek çok ülkede beklenenin aksine olumsuz sonuçlar doğurmuştur. Yüksek enflasyon, artan cari açık (Fellows, 2006), üretken sektörlerden sermaye kaçışı, yeni yatırım yetersizlikleri (Aveline ve Li, 2004), inşaat ve ilişkili sektörlerle ilgilenen şirketlerin iflasları bu sonuçların ekonomi kanadını oluştururken yapı stokunda aşırı düzeyde artış, arz fazlası neticesinde ortaya çıkan yüksek stok boşluk oranları, doğal çevrenin inşa sahaları açmak için tahrip edilmesi (Balaban, 2011; Özdemir Sarı, 2019) mekânsal sorunları oluşturmaktadır.

Bahsi geçen tüm bu değişimler ışığında Türkiye'de inşaat ve konut sektörlerinin geçmiş deneyimleri ve gelecek beklentilerinin değerlendirilip güçlü ve dayanıklı olduğu söylemi tartışmaya açılmıştır. Değerlendirmeye ekonomiye girdi olarak inşaat sektöründe (inşaat sektörü ile ilgili şirketlerin niceliksel değişimi ve inşaat sektörü gelecek beklentisi) gözlemlenen değişkenlerle başlanmıştır. Daha sonra faaliyetler sonucunda sırasıyla üretilen bir çıktı olarak konut sektöründe (konut üretim ve satış düzeyleri, konut mülkiyet şekli) ve konutun varlık olarak değerini oluşturan reel konut fiyatları değişimleri, konut fiyatının hane halkının kullanılabilir gelirine oranı ve konut fiyatı izafi kira oranı değişkenleri altında kırılganlığa sebep olabilecek etmenler tartışılmıştır.

\subsection{Girdi olarak inşaat sektörünün kırılganlığı}

Konutun bir varlık ve çıktı ürün olarak değerlendirilmesi ve kırılganlıklarının saptanmasının ardından inşaat sektörüne girdi sağlayan değişkenlere odaklanılmıştır. İlk olarak inşa etme ve satış sürecine doğrudan dahil olan yeni kurulan ve kapanan inşaat ve gayrimenkul şirketlerinin 2010-2018 yılları içinde toplam şirketler içindeki payları incelenmiştir. Son iki yıllık sürede kapanan inşaat şirketlerinin (inşaat ve gayrimenkul) toplam kapanan şirketler içinde oranının iki kat arttığı görülmektedir (Şekil 3). 2015 yılından itibaren kurulan inşaat şirketlerinin toplam kurulan şirketler içindeki payının durağanlaşması da dikkat çeken bir diğer göstergedir.

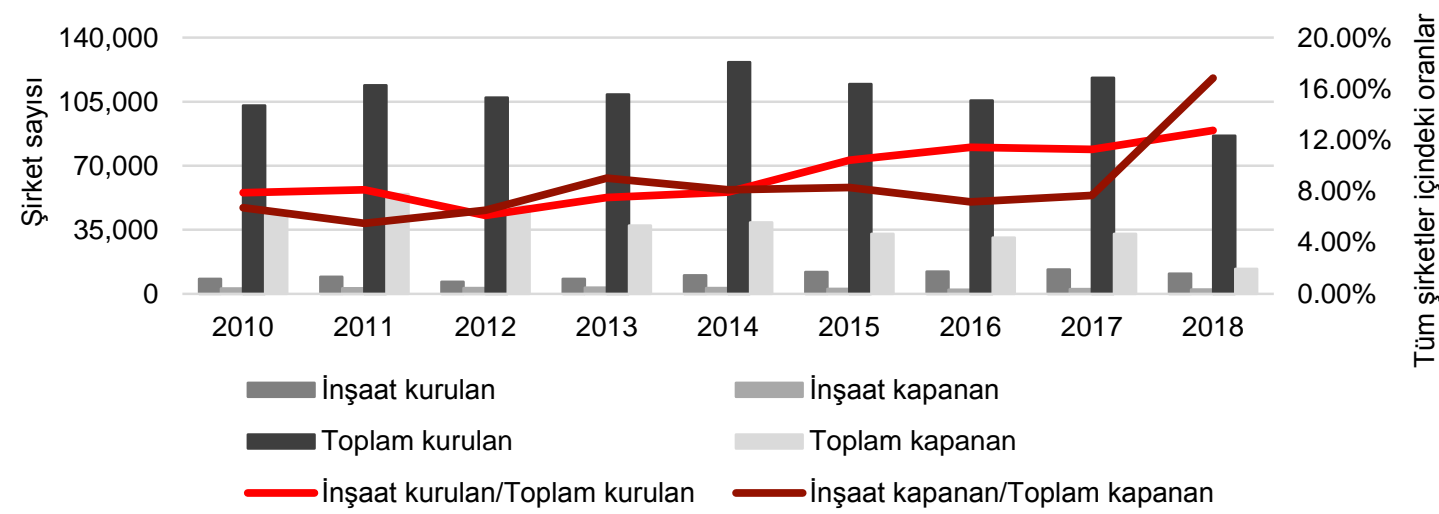

Şekil 1. İnşaatla ilgilenen şirketlerin niceliksel değişimi

Yukarıda bahsedilen niceliksel değişimlere göre son 4 yılda inşaat sektörü yeni girişimci yönünden eski hareketli günlerini yaşayamazken aşırı konut üretiminin beraberinde getirdiği satılamayan konutlar da iflas eden şirketlerin oranındaki artışı açıklamaktadır. Kapanan şirketlerin artan oranını doğrudan veriye erişmek mümkün olmasa da risk taşıdığı gerekçesiyle kentsel dönüşüme uğraması hedeflenen eski konutun yıkılıp yenisinin inşasının başlayamadığı ya da tamamlanamayan konut inşaatlarından da yorumlamak mümkündür. Ayrıca 2019 yılı mart ayında yayınlanan 6306 sayılı kanun kapsamında yönetmelik değişikliğiyle beraber yarım kalan inşaatların sayısını azaltmak amacıyla Çevre ve Şehircilik Bakanlığı bazı tedbirler almıştır. Bu tedbirlerden ilki kentsel dönüşümde projelerinde yeterlilikleri belirleyen sınıflandırmadır. Bu sınıflandırma kentsel dönüşüm projelerine sadece 
teknik ve mali yeterliliği bulunan firmaların girmesini sağlamayı hedeflemiştir. Bu tedbire ek olarak kentsel dönüşüm projesi yürütmeye yeterli olduğu tespit edilen firmalara yapı maliyetinin yaklaşık \%10'u oranında teminat mektubu ya da tamamlama sigortaları yapmaları kaydıyla ilgili işe başlayabilme koşulu getirilmiştir.

İş Yeri Eğilim İstatistiklerinden biri olan İnşaat Sektörü Eğilim Çalışması ilgili işin yöneticisi ile görüşülerek oluşturulan inşaat faaliyetlerinin niteliği ve niceliği, faaliyetlerini kısıtlayan faktörleri, alınan siparişler, çalışan sayısı, satış fiyatları, faaliyetlerin arttırılabilme durumu ve yatırım konularında mevcut durum değerlendirmeleri ile gelecek dönem beklentilerini ölçmekte kullanılan bir çalışmadır. Araştırma sektörün mevcut durumu ve gerçekleşmesi muhtemel değişikliklerin öngörülmesi ve Sektörel Güven Endeksi oluşturmayı amaçlamaktadır. Her ay gelecek üç aylık dönem içerisindeki beklentileri somutlaştıran bu veri seti 2011-2019 yılları için bir araya getirilmiştir. Özellikle 2017 yılından itibaren İnşaat Sektörünün geleceğine duyulan güven, çalışan sayısı beklentisi ve satış fiyatları beklentisinde ciddi düşüşler yaşanmaktadır (Şekil 4).

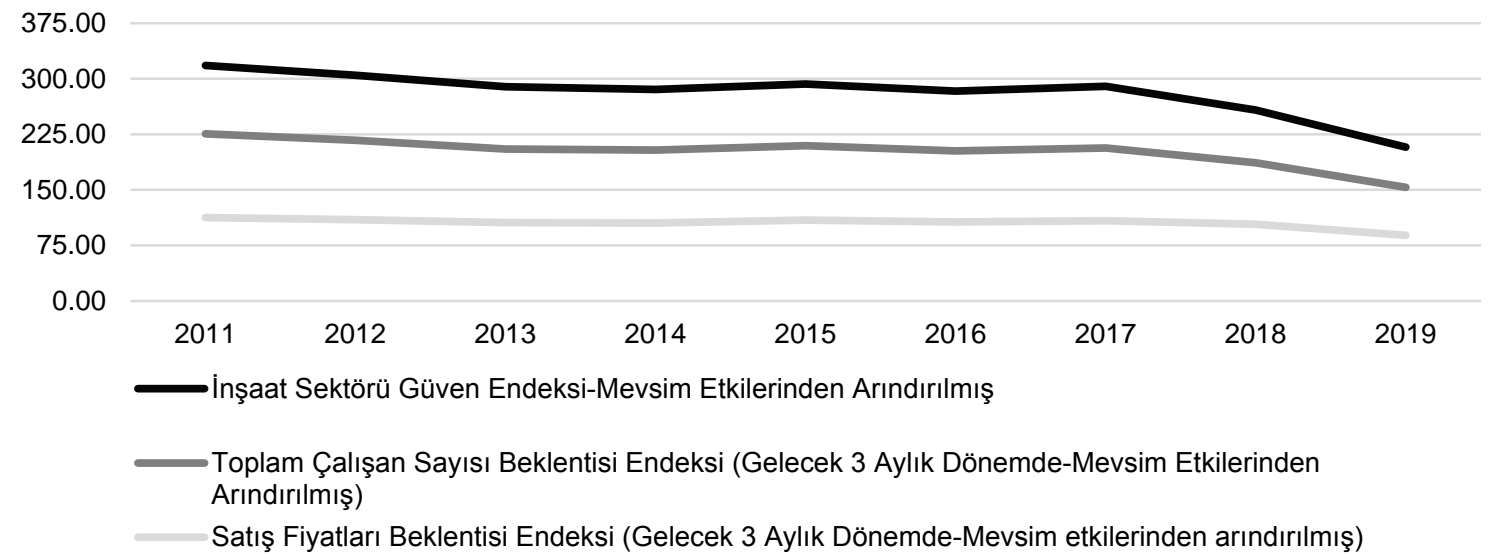

Şekil 2. İnşaat sektörü gelecek beklentisi

Sektöre yönelik beklentiler açılan ve kapanan inşaat şirketlerinin oranlarıyla beraber değerlendirildiğinde iflas eden inşaat şirketleri kadar kendi isteğiyle faaliyetine son veren şirketlerin de olma ihtimali göz ardı edilmemelidir.

\section{2. Çıktı olarak konutun kırılganlığının saptanması}

Konutun belirli süreçler sonucunda üretilen bir çıktı, ürün olarak ele alındığı bu kısımda konut piyasasının arz talep dengesine göre aşırı birikme durumunda karşı karşıya kalacağı kırılganlığı saptanacaktır. Türkiye'de konut piyasası son yıllarda yüksek konut üretim seviyesi, yeni konut birimlerinin toplam konut satış payındaki düşüş ve ev sahipliğinde azalan oranlarla gündemde olmuştur (Özdemir Sarı ve Aksoy Khurami, 2018). İnşasına başlanan konut birimi sayısı 2014-2017 yılları arasında 4.000.000'u geçmiştir. Ancak ilk el konut stokunda yer alan (yeni imara açılan alanlarda inşa edilen ya da kentsel dönüşümle yenilenen konut dokusunda yer alan stokun oluşturduğu) konutların satışının toplam satıştaki payı 2013 yılının ilk çeyreğinden beri dalgalanmakla beraber düşme eğilimindedir (Şekil 2). Öte yandan ipotekli konut satışlarının oranında 2017 yılının ilk yarısından itibaren göze çarpan düşüş dikkat çekmektedir. Bu sonuca göre Türkiye'de banka kredilerini kullanarak konut almayı tercih eden ya da kredilendirme kuruluşları açısından konut kredilerinden yararlanması risksiz olan hane halklarının oranı her geçen gün düşmektedir. 


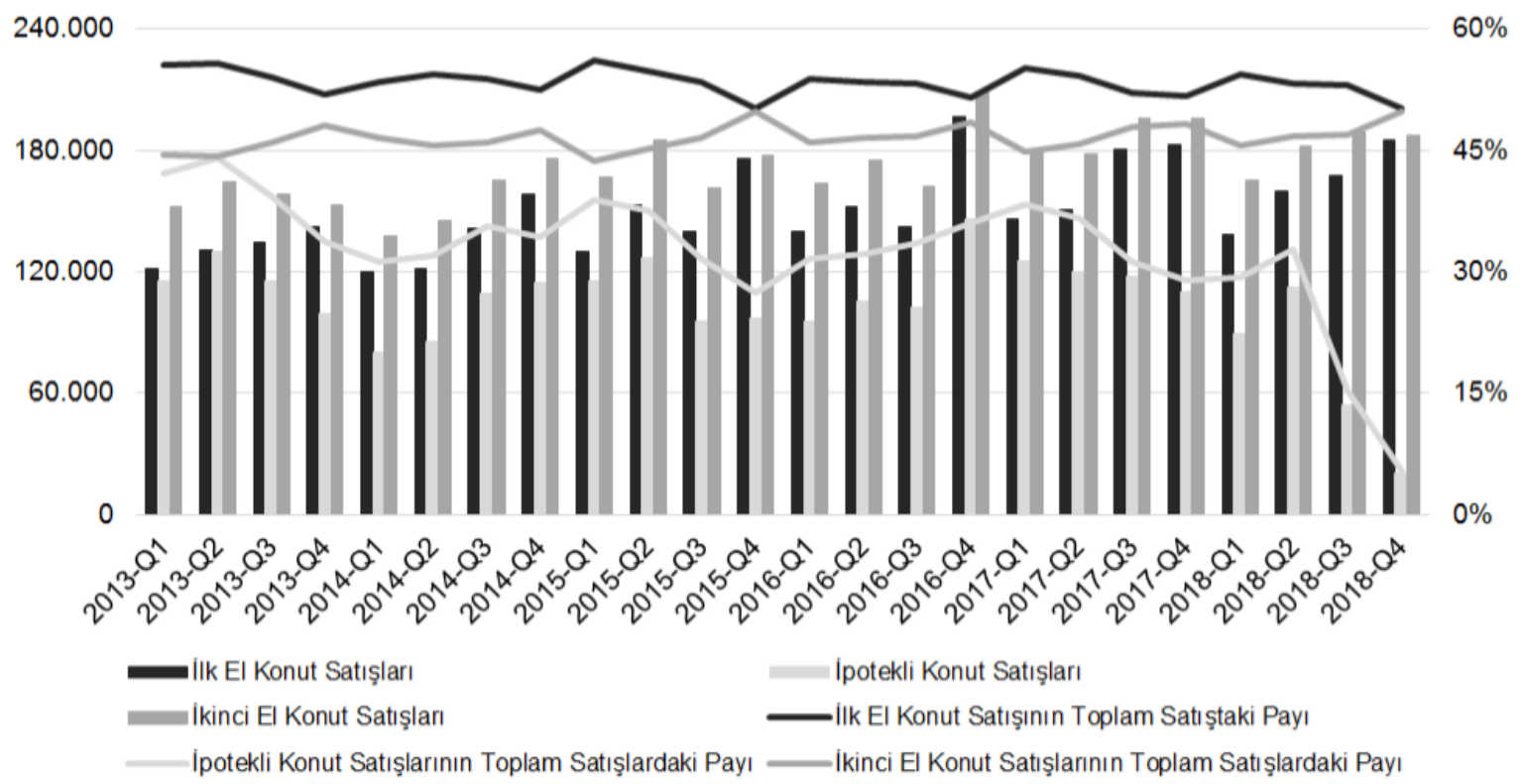

Şekil 3. Konut Satış İstatistikleri

Konut sunumunun sektör faaliyetlerinin bir çıktısı olarak değerlendirildiği bu kısımda konut sahibi olan ve konuta ilişkin borcu olan konut sahibi hane halklarının değişimi gözlenmiştir. Kamu politikalarının temel motivasyonunu oluşturan konut sahibi olan hane halklarının arttırılması hedefi üretilen yeni konut birimlerine rağmen beklenen sonuca ulaşamamıştır. 2005 ve 2016 yılları arasında ev sahibi olan hane halklarının oranında yüzde 5,1'lik azalma dikkat çekmektedir (Tablo 2). Öte yandan aile ya da bir yakınının evinde piyasa fiyatlarının altında bir kira ödeyerek ya da hiçbir ücret ödemeden ikamet eden diğer hane halklarının oranında gözle görülür bir artış bulunmaktadır. Aynı yıllar arasında konut sahibi olan hane halkları içinde devam eden bir konut borcu olan hane halklarının oranında da artış gözlenmiştir. Bu duruma konut finansman sisteminde 2007 yılında yapılan değişikliklerin katkı sağladığı düşünülse de ipotekli konut satışlarının toplam konut satışları içindeki payının düşük olması hane halklarının kredilendirme kuruluşlarından ziyade diğer kaynaklardan borç alma intimalini ortaya çıkarmaktadır.

Tablo 2. Konut mülkiyet şekli ve borçlu ev sahipleri oranlarının değişimi

\begin{tabular}{llll}
\hline Değişken & Değişken açıklaması & $\mathbf{2 0 0 5}$ & $\mathbf{2 0 1 6}$ \\
\hline Ev sahibi & Toplam hane halkları içinde & 68,30 & 63,20 \\
Kiracı & dağılımı (\%) & 23,40 & 21,30 \\
Diğer hane halkları & & 7,30 & 13,60 \\
\hline Ev sahibi olup konut borcu olan & Ev sahibi hane halkları içinde & 4,20 & 15,40 \\
En sahibi olup konut borcu olmayan & dağılımı (\%) & 95,80 & 84,60 \\
\hline
\end{tabular}

\subsection{Varlık olarak konutun kırılganlığının saptanması}

Hane halklarının konut satın alırken sahip olduğu motivasyonlardan biri olan konutun varlık değeri taşıması özelliği doğrudan konutun fiyatıyla iliş̧ili bir değişkendir (Wind, 2017). Kiralık stoktan yararlanmak ve konut sahibi olmak arasındaki tercihi de belirleyen varlık değerini aynı zamanda hane halkının benzer bir konuta ödeyeceği kira değeri ve hane halkının geliri ilişkisiyle değerlendirmek de mümkündür. 
Konut fiyat endekslerinin hesaplanmasında satışa konu olan tüm konutlara ilişkin fiyat verileri kullanılmaktadır. Satışın gerçekleşerek kredinin kullandırılması şartı aranmamakta, değerlemesi yapılan tüm konutlar kapsama dahil edilmektedir. Yeni konutlar son iki yıl içinde yapılan konutları ifade ederken yeni olmayan konutlar yapım yılı ikiden fazla olan konutları ifade etmektedir. Türkiye'de hedonik regresyon yöntemi kullanılarak hesaplanan konut fiyat endekslerine göre yeni konut sunumunda rekor düzeylere ulaşmasına rağmen 2015 yılının ilk çeyreğinden itibaren yeni olmayan konutların fiyat endeksi yeni konutlardan yüksektir (Şekil 1). Yeni olmayan konutların fiyatının yeni konutlara göre daha fazla artması birden fazla yorumu içinde barındırmaktadır. İlk seçenek hane halklarının aldıkları yeni konuta ilişkin ödemeleri yapmakta zorlanıp kısa süre içerisinde konutlarını daha düşük değerlere satmalarıdır. Bir başka değerlendirme ise hane halklarının yeni olmayan konutlarına ilişkin borçları olmadığı kabulüne dayanarak konut satış sürecini uzattıkları ve konut fiyatında indirime gitmedikleridir. Ayrıca yeni olmayan konutlar nasıl olsa bir gün kentsel dönüşüme girecek anlayışıyla hane halkları tarafından daha yoğun talep görmekte ve bu durum fiyat endeksinde yeni konutlara kıyasla daha fazla artışa sebep olmaktadır. Konut fiyat endeksi değişiminden çıkarılan sonuçlara göre üretimine ağırlık verilen yeni konutlar satılamadan birikme riskiyle karşı karşıyadır.

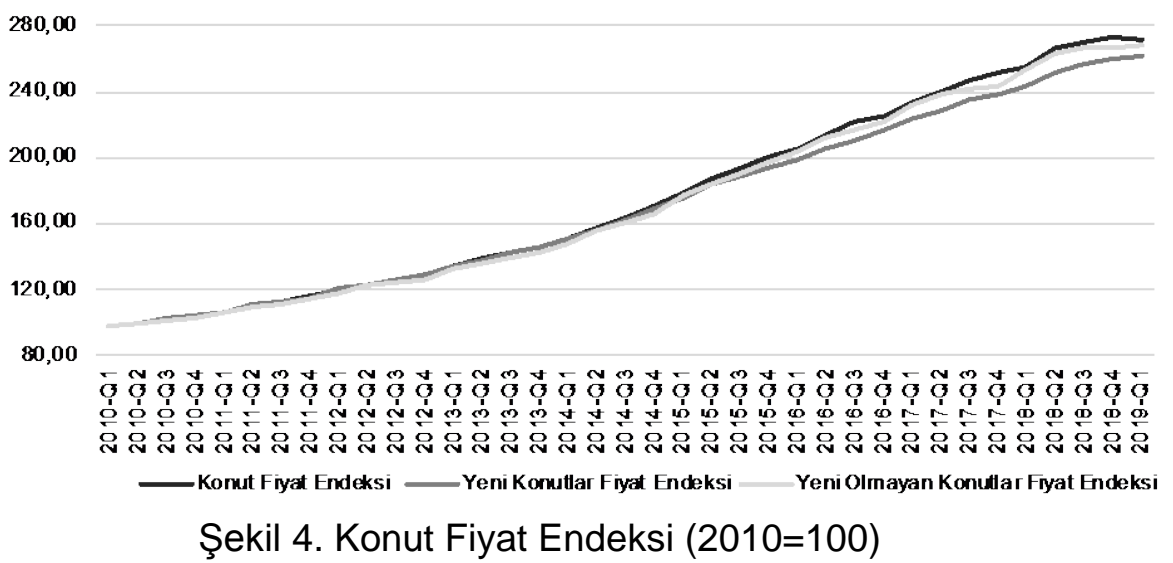

Hane halklarının ev sahipliği ve kiracılık arasındaki tercihlerini belirleyen iki etmen olan konut fiyatının hane halkının benzer bir ev için ödeyeceği kiraya oranı ve konut fiyatının yıllık kullanılabilir gelire oranı genellikle yapılacak yatırımın makullüğünü saptamakta kullanılmaktadır. Analize konu olan 2005 ve 2016 yılları için TÜíK tarafından toplanan Hane Haklı Bütçe Anketi Mikro Veri Seti'ne göre konut fiyatının yıllık izafi kiraya oranı 19,79'dan 22,22 ye çıkmıştır. Kesin bir kabulü olmamakla beraber genellikle 1-15 arası değerler konut sahibi olmanın o birimde kiracı olmaktan daha anlamlı olduğunu, 16 ve üstünde yer alan değerler ise ilgili birim için kiracı olmanın daha avantajlı olduğunu vurgular. Türkiye için her iki yıl içinde medyan değerlere göre ev sahibi olmak makul bir yatırım olarak gözükmemektedir.

Kredilendirme kuruluşlarının uzun yıllardır yararlandığı konut kredisinden yararlanacak hane halklarının belirlenen minimum kredi peşinatını ödedikten sonra mevcut gelirleri ile yapılması planlanan aylık ödemelerini gerçekleştirememe riskini hesaplamakta kullandığı konut fiyatının hane halkı kullanılabilir gelirine oranını son yıllarda hane halkları da sıklıkla kullanmaya başlamıştır. Konut fiyatı/gelir oranındaki artış en basit yorumuyla hane halkları için alınması planlanan konutun daha az ekonomik hale geldiğini, kredi kuruluşları açısından ise ilgili konut kredisini kullandırmanın riskli olabileceğini gösterir. Türkiye genelinde yapılan analizde ilgili oranın 2005 yılında 2,81 iken 2016 yılında 4.75'e çıktığı görülmektedir. Bu da konut sahipliğinin hane halkları ve kredilendirme kuruluşları için ekonomik ve risksiz bir yatırım olmaktan çıktığını göstermektedir. 


\section{DEĞERLENDIRME}

$\mathrm{Bu}$ çalışmanın temel bulgularına göre olası senaryolara geçmeden önce birkaç noktanın vurgulanmasından fayda bulunmaktadır. Konutun sahip olduğu varlık değerine göre yapılan saptamalarda ilk olarak yeni olmayan konut fiyatlarının beklenenden (yeni konutlardan) daha çok arttığı ancak konut yatırımı yapmanın mevcut konut fiyatları, gelir düzeyi ve izafi kira değerlerine göre ekonomik olmadığı tespit edilmiştir. Dar gelirli hane halklarının satış fiyatlarındaki düşüklük sebebiyle önceki dönemlerde tercih ettiği yeni olmayan konut dokusunun güncel koşullarda bu kabule uymadığı gözlenmiştir. Ancak konut piyasasının kendi içerisinde pek çok alt piyasayı barındırdığı ve bu değerlendirme de coğrafi olarak tüm ülkeyi kapsayan verilerden yararlanıldığı göz önünde bulundurulmalıdır. Bu sonuç beraberinde satın alma için gerekli tüm koşullar sağlandığı durumda dahi dar gelirli hane halklarının yeni ve çoğunlukla lüks olan yeni konut birimlerinin aidat ve yüksek bakım giderlerini nasıl karşılayacağı sorusunu gündeme getirmektedir.

Konutun çıktı ürün olarak değerlendirildiği aşamalarda ise konut üretim düzeyindeki aşırılık ile beraber ev sahipliği oranının artmaması dikkat çekmiştir. Konut üretim politikasının hedefine ulaşamaması (en sahibi olan hane halklarının oranının artmaması) üretilen bu birimlerin satılan kısmının kim tarafından satın alındığı sorusunu tartışmaya açmıştır. Satın alınan bu konutları hali hazırda ev sahibi olan hane halklarının aldığı tahmin edilmektedir. Öte yandan diğer hane halkı (aile ya da bir yakınının evinde oturan) kategorisindeki artış bu tahmini destekler niteliktedir. Konutların satın alınmasını birden çok konut sahibi olan hane halklarıyla açıklamak mümkün olurken satılamayan konutlar için konut finansman sistemi ve sorunları akla gelmektedir. Hane halkları mevcut piyasa koşullarında bir konut biriminde kiracı olarak ikamet ederken aynı zamanda konut kredisi için peşinat biriktirmekte zorlanmaktadır. Hane halklarının bu birikimi gerçekleştirdiği varsayıldığında dahi ilgili kredilendirme kuruluşu tarafından kredi verilmeye uygun bulunmama ihtimalleri de bulunmaktadır. Konut finansmanını geleneksel yöntemlerle sağlamaya çalışan hane halklarının da güncel koşullarda bir konutu satın almaya yetecek miktarı edinemediği düşünülmektedir.

İnşaat sektörünün (ekonomik) girdi olarak değerlendirildiği kısımda ilk olarak kapanan inşaat şirketlerinin sayısı ve oranı ortaya konmuştur. İflasını ilan eden ya da iflas etmeden faaliyetini durduran bu firmaların halı hazırda konut inşa işleri aldığı ancak ya hiç başlamadığı ya da yarım bıraktığı bilinmektedir. Bu durumda bu inşaatları kimin tamamlayacağı ve mülk sahiplerinin bu süreçte nasıl bir yol izlemesi gerektiği muallaktır. Son olarak ekonomik sektör olarak inşaat ve konutun istihdam boyutu da bulunmaktadır. İş gücü eğilim istatistiklerinde ortaya konduğu üzere şirketlerin kapanması veya küçülmeye gitmesiyle sektörde çalışan kişi sayısında da bir düşüş olacaktır.

İnşaat ve konut sektörlerine ağılık verilmeye devam etmesi durumunda karşılaşılması olası birkaç senaryodan bahsedilebilir. Bu durum ilk olarak konut marketinin sahiplik bakımından paydaşı olan ve olmayan hane halkları arasında ciddi bir ayrım yaratacaktır. Geleneksel finansman yöntemlerinden yararlanamamanın da etkileyeceği hane halkları için konut sahipliği aileden gelen bir kader haline gelecektir. Günümüzde tam olarak gözlenemese de bazı hane halklarının mülksüz bazılarının ise çoklu konut sahibi olacağı düşünülmektedir. Bu sonuç mülksüz hane halklarının konut sorununu çözmeye yönelik çeşitli ve çok yönlü konut politikalarının gerekliliğini ortaya koymaktadır.

İkinci olarak konut üretim ve satış düzeylerinin kentsel dönüşümün sürdürülebilirliğini sorgulatacağı düşünülmektedir. Talebi olmayan bir arzın bir müddet sonra yeni konut üretimini hedefleyen inşaat faaliyetlerini durma noktasına getireceği olasıdır. Öte yandan konut inşaatlarının tamamlanmasını amaçlayan düzenlemelerin büyük ve küçük ölçekli 
inşaat firmalarını farklı düzeylerde etkileyeceği düşünülmektedir. Küçük olduğu için hem nitel hem de nicel açıdan proje yürütmede yeterli olamayacağı düşünülen bu firmaların varlıklarını sürdüremeyecekleri karşılaşılacak muhtemel sonuçlardandır. Ancak öte yandan büyük inşaat firmalarının da tek bina ölçeğinde konut üretimi gerçekleştirmemesi mevcut dokunun dönüşümü-yenilenmesi için geliştirilmesi gereken yeni araçları gündeme getirmektedir.

\section{KAYNAKLAR}

Adger, W.N. (2000). Social and Ecological Resilience: Are They Related? Progress in Human Geography 24, 347-364.

Alberti, M. ve diğerleri. (2003). Integrating humans into ecosystems: Opportunities and challenges for urban ecology, BioScience, 53, 1169-1179.

Aveline, N. ve Li, L.H. (Ed.) (2004). Property markets and land policies in northeast Asia, the case of five cities: Tokyo, Seoul, Shanghai, Taipei and Hong Kong. Maison FrancoJaponaise and Centre of real estate and urban economics HKU.

Balaban, O. (2011). İnşaat Sektörü Neyin Lokomotifi? Birikim, 270, 19-26.

Callister, W. D. (2000). Materials science and engineering (5th ed.) New York: Wiley.

Christopherson ve diğerleri. (2010). Regional resilience: Theoretical and empirical perspectives, Cambridge Journal of Regions Economy and Society, 3, (1), 3-10.

Downing, T. E. ve diğerleri. (2005). Integrating social vulnerability into water management. SEI Working Paper and Newater Working Paper No. 4. Stockholm Environment Institute, Oxford, UK

Ionescu, C. ve diğerleri. (2009). Towards a formal framework of vulnerability to climate change, Environmental Modeling and Assessment, 14, (1), 1-16.

Fellows, R. F. (2006). Escalation management: Forecasting the effects of inflation on building projects, Construction Management and Economics, 9, (2), 187-204.

Godschalk, D. R. (2003). Urban hazard mitigation: Creating resilient cities, Natural Hazards Review, 4, (3), 136-143.

Hermansen, M. ve Röhn, O. (2015). Economic resilience: The usefulness of early warning indicators in OECD countries, Economic Department Working Papers No.1250.

Lo Duca, M. ve T. Peltonen (2013). Assessing Systemic Risks and Predicting Systemic Events, Journal of Banking and Finance, 37, (7), 2183-2195.

Özdemir Sarı, Ö.B. ve Aksoy Khurami, E. (2018). Housing affordability trends and challenges in the Turkish case, Journal of Housing and the Built Environment (online first) https://doi.org/10.1007/s10901-018-9617-2.

Özdemir Sarı, Ö.B. (2019). Redefining the Housing Challenges in Turkey: An Urban Planning Perspective. In: Ö. Burcu Özdemir Sarı, Suna Senem Özdemir, Nil Uzun (Eds.), Urban and Regional Planning in Turkey (p. 167-184) The Urban Book Series, Switzerland: Springer. 
Rose, A. ve M. Spiegel (2011). "Cross-country Causes and Consequences of the Crisis: An Update",

Special Issue: Advances in International Macroeconomics: Lessons from the Crisis, European

Economic Review, 55, (3), 309-324.

Röhn, O. ve diğerleri. (2015). Economic resilience: A new set of vulnerability indicators for OECD countries, Economics Department Working Papers No.1249.

T.C. Merkez Bankası, Konut ve İnşaat İstatistikleri (2013-2018).

TOBB. Kurulan/Kapanan Şirket İstatistikleri (2010-2018).

TÜíK. (2011-2019). İş Yeri Eğilim İstatistikleri.

TÜIKK. (2005-2016). Hane Halkı Bütçe Anketi, Mikro Veri Seti.

Wind, B. (2017). Housing wealth in Europe: Institutions and inequality. s.l.: GVO drukkers \& vormgevers B.V. | Ponsen \& Looijen. 